\title{
AUDIT MANAJEMEN TERHADAP FUNGSI PEMAKAIAN BAHAN BAKU PADA CV. MAJU MAPAN DI TULUNGAGUNG
}

\author{
Marlena \\ Universitas Tulungagung \\ cahayoe.n42@gmail.com \\ Ahmad Anton Purnomo \\ Universitas Brawijaya Malang
}

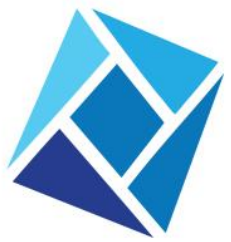

\section{Jurnal Nusantara} Aplikasi Manajemen Bisnis

http://ojs.unpkediri.ac.id/index. $\mathrm{php} / \mathrm{manajemen/index}$

E-ISSN : 2528-0929

P-ISSN : 2549 - 5291

Diterima: 08 Februari 2018

Revisi : 26 Maret 2018

Disetujui: 18 April 2018

https:doi.org 10.29407nusamba. v3i1.12030

\begin{abstract}
CV. Maju Mapan is a company engaged in the production of military equipment equipment. This study aims to determine the effectiveness of the function of the use of raw materials. And the object of this research is the use of raw materials on the CV. Advanced in Tulungagung.

The method used in this research is descriptive testing which is a research problem in the form of facts of the object of research with the aim of providing an overview of the problems encountered, or know how to solve the problem.

Data analysis techniques used are qualitative and quantitative methods. From result of analysis obtained show difference of planning and realization in year 2016 difference of effectivity of use of raw material of polyester fabric 0,74\%, fabric puring $0,73 \%$, webbing polyester $0,72 \%$. Surely the difference can disrupt the production process so it is necessary to make repairs to damaged products. Then $C V$. Forwardly Mapan needs to make efforts to suppress the difference in the use of raw materials to close to $0 \%$ so as to achieve maximum effectiveness.

Kata Kunci: Audit management, use of raw materials, effectiveness Abstrak

CV. Maju Mapan merupakan perusahaan yang bergerak dibidang produksi perlengkapan peralatan TNI. Penelitian ini bertujuan untuk mengetahui efektifitas terhadap fungsi pemakaian bahan baku. Dan yang menjadi objek penelitian ini adalah bagian pemakaian bahan baku pada CV. Maju Mapan di Tulungagung.

Metode yang digunakan dalam penelitian ini adalah pengujian deskriptif yang merupakan penelitian masalah berupa fakta dari objek penelitian dengan tujuan memberikan gambaran terhadap masalah yang dihadapi, atau mengetahui cara pemecahan masalah.

Teknik analisis data yang digunakan adalah metode kualitatif dan kuantitatif. Dari hasil analisis yang diperoleh menunjukkan selisih perencanaan dan realisasi pada tahun 2016 selisih efektifitas pemakaian bahan baku kain polyester $0.74 \%$, kain puring $0.73 \%$, webbing polyester $0.72 \%$. Tentunya selisih tersebut dapat mengganggu proses produksi sehingga perlu untuk melakukan perbaikan ulang terhadap produk rusak. Maka CV. Maju Mapan perlu melakukan upaya untuk menekan selisih pemakaian bahan baku hingga mendekati $0 \%$ sehingga dapat mencapai efektifitas maksimal.
\end{abstract}

Kata Kunci : Audit manajemen, pemakaian bahan baku, efektifitas 


\section{Pendahuluan}

Dalam bidang industri diketahui bahwa tingkat persaingan semakin keras sehingga perusahaan dituntut untuk lebih selektif. Agar dapat bertahan dan bersaing maka dalam proses pengelolaannya pun perlu diperhatikan, salah satunya dengan mengoptimalkan efektifitas pemakaian bahan baku dalam proses produksi. Selain itu dalam proses produksi tersebut diperlukan alat bantu yang berperan sebagai audit manajemen, disamping itu dalam menjalankan perusahaan tidak lepas dari kebutuhan akan informasi tentang berbagai bagian dari perusahaan agar manajemen dapat mengarahkan perusahaan menjadi lebih baik. Berdasarkan fungsinya audit manajemen berbeda dengan audit akuntansi, audit akuntansi lebih menyangkut pada transaksi financial, perkiraan laporan keuangan, pemberian pendapat terhadap kewajaran dalam penyajian laporan keuangan. Sedangkan audit manajemen akan lebih mengarah kedalam efektifitas pengelolaan dan penggunaan bahan baku serta sarana dan prasarana perusahaan. Dalam menghadapi dunia usaha yang semakin kompetitif tersebut, perusahaan perlu mempertimbangkan secara serius untuk mempergunakan manajemen audit, guna mencapai tingkat efektifitas yang optimal sehingga dalam penggunaannya menjadi lebih efisien.

Fungsi produksi yang efekitif ini merupakan suatu kunci keberhasilan sebuah perusahaan karena dapat memberikan sejumlah keuntungan yang lebih besar bagi perusahaan. Laba perusahaan menjadi indikator bahwa perusahaan dapat dikatakan baik dan mampu mempertahankan kelangsungan perusahaan tersebut. Peningkatan laba perusahaan akan tergantung pada sejauh mana sumberdaya digunakan secara efektif sehingga perusahaan memerlukan pengevaluasi terhadap efektifitas proses produksi perusahaan.

Terdapat beberapa alasan mendasari perlunya dilakukan audit pada proses produksi, apakah berjalan sesuai dengan prosedur yang telah ditetapkan, perusahaan dapat menemukan kekurangan yang terrjadi sehingga dapat diperbaiki, konsistensi berjalannya proses perlu diungkapkan dan pendekatan proaktif harus menjadi dasar pengenaan proses. Disamping itu berjalannya tindakan korektif harus mendapat dorongan dan dukungan dari berbagai pihak yang terkait.

Audit manajemen ditujukan pada seluruh bagian dalam perusahaan, namun dalam kebutuhannya dapat pula ditujukan dalam satu bagian dalam perusahaan. Dalam Audit manajemen ini dapat ditujukan dalam perusahaan yakni audit manajemen terhadap fungsi pemakaian bahan baku pada CV. Maju Mapan.

\section{PERMASALAHAN}

Masalah yang dihadapi setiap perusahaan bermacam-macam. Semakin besar suatu perusahaan maka masalah yang dihadapi akan semakin kompleks.

Masalah yang dapat diidentifikasi penulisan adalah sebagai berikut :

1. Bagaimanakan pengelolaan bahan baku perusahaan?

2. Apakah perusahaan telah melakukan audit manajemen terhadap pemakaian bahan baku?

3. Apakah perusahaan telah mengelola bahan baku tersebut secara efektif?

\section{TUJUAN PENELITIAN}

Penelitian ini bertujuan untuk mengetahui efektifitas dalam hal pemakaian bahan baku, dan dapat menjadi pertimbangan dalam pengembangan perusahaan.

\section{KAJIAN PUSTAKA}

\section{Audit manajemen terhadap fungsi pemakaian bahan baku}

Audit manajemen terhadap fungsi pemakaian bahan baku merupakan suatu bentuk audit yang dilaksanakan perusahaan dengan tujuan untuk mengetahui tingkat efisiensi dan efektivitas kegiatan dibidang produksi. Selain itu, produksi juga berfungsi untuk mengukur seberapa baik manajemen menjalankan fungsi perencanaan, organisasi, pelaksanaan, dan 
pengawasan kegiatan produksi dan seberapa efektifkah manajemen dalam membuat keputusan yang tepat untuk mencapai tujuan produksi yang telah ditetapkan.

Menurut Bayangkara (2008:177), audit produksi melakukan penilaian secara komprehensif terhadap keseluruhan fungsi produksi dan operasi untuk menentukan apakah fungsi ini telah berjalan dengan memuaskan (ekonomis, efektif, dan efisien). Beberapa alasan yang mendasari perlunya dilakukan audit produksi, antara lain :

a. Proses produksi dan operasi harus berjalan sesuai dengan prosedur yang telah ditetapkan.

b. Kekurangan/kelemahan yang terjadi harus ditemukan sehingga segera dapat diperbaiki.

c. Konsistensi berjalannya proses harus diungkapkan.

d. Pendekatan proaktif haras menjadi dasar dalam peningkatan proses.

e. Berjalannya tindakan korektif harus mendapat dorongan dan dukungan dari berbagai pihak yang terkait.

\section{METODE PENELITIAN \\ Objek Penelitian}

Penelitian ini dilaksanakan pada CV Maju Mapan yang berlokasi di Jl. Raya I/26 Desa Ngunut Kecamatan Ngunut Kabupaten Tulungagung. Dalam pemilihan lokasi penelitian ini ditentukan penulis berdasarkan pertimbangan bahwa didalam perusahaan perlu diadakan audit manajemen yang ditujukan pada bagian dalam perusahaan, dalam hal ini objek penelitian merupakan fungsi pemakaian bahan baku.

\section{Metode dan Desain Penelitian}

Metode penelitian yang digunakan adalah pengujian deskriptif yang merupakan penelitian masalah berupa fakta dari objek penelitian dengan tujuan memberikan gambaran terhadap masalah yang dihadapi, atau mengetahui cara pemecahan masalah atau menjawab pertanyaan yang berkaitan dengan permasalahan yang diteliti.

Dalam pelaksanaan metode deskriptif ini teknik yang digunakan adalah teknik studi kasus yang merupakan penelitian dengan karakteristik masalah yang berkaitan dengan latar belakang dan kondisi saat ini terhadap subjek penelitian.

Desain yang digunakan dalam pelaksanaan penelitian ini berupa :

a. Identifikasi masalah.

b. Merumuskan masalah dan tujuan penelitian.

c. Menentukan unit studi yang akan digunakan dalam penelitian.

d. Menentukan teknik pengumpulan data.

e. Mengorganisir serta menganalisa data dan informasi yang terkumpul.

f. Menyusun laporan dengan memberikan kesimpulan serta rekomendasi perbaikan dari hasil penelitian.

\section{Teknik Pengumpulan Data}

Data yang valid dihasilkan dari teknik pengumpulan data yang baik, agar dapat menghasilkan penelitian yang baik. Jenis data yang digunakan dalam penelitian ini adalah data primer dan sekunder yang bersifat kualitatif maupun kuantitatif. Data primer merupakan data yang diperoleh dari sumber langsung tanpa perantara, dan sekunder merupakan data yang dikumpulkan melalui perantara orang lain atau sumber lain atau data dalam bentuk jadi, dalam hal ini gambaran umum perusahaan, dan pemakaian bahan baku.

Teknik pengumpulan data terkait dengan jenis dan sumber data meliputi : 

a. Teknik wawancara
Merupakan suatu proses memperoleh informasi dengan menggunakan tanya jawab.
b. Teknik observasi
Merupakan suatu teknik pengumpulan data dengan cara mengamati langsung pada objek penelitian
c. Teknik dokumentasi
Merupakan pengumpulan data yang dilakukan dengan mengadakan pencatatan langsung dari kata - kata yang ada pada perusahaan terkait objek yang dituju.

\section{Teknik Analisis Data}

a. Kualitatif

Suatu cara menganalisa data tanpa menggunakan perhitungan perhitungan matematis yang bersifat interpretasi data yang dilakukan dengan membandingkan data yang diperoleh dengan teori yang ada.

Tahap analisis data dalam hal ini seperti tahap audit manajemen itu sendiri, yaitu pemeriksaan pendahuluan, review dan pengujian sistem Pengendalian Manajemen, pemeriksaan terinci dan pelaporan.

b. Kuantitatif

Dengan menggunakan perhitungan antara rencana dan realisasi :

RKAP - Jumlah realisasi pemakaian pada akhir periode

$\frac{\text { RKAP }}{(R K A P=\text { Rencana Kerja Anggaran Perusahaan })}$

\section{PEMBAHASAN}

Untuk mengetahui apakah CV. Maju Mapan telah melaksanakan pengendalian manajemen terhadap fungsi pemakaian bahan baku, maka penulis perlu melakukan analisis system pengendalian manajemen terhadap hasil audit yang telah dilakukan pada CV. Maju Mapan. Dalam hasil audit yang telah dilakukan, maka penulis akan melakukan analisis terhadap efektifitas dalam fungsi pemakaian bahan baku.

\section{Sistem Pengendalian Manajemen}

Dalam penelitian ini penulis memfokuskan pada audit manajemen terhadap fungsi pemakaian bahan baku pada CV. Maju Mapan di Tulungagung. Berikut ini merupakan sistem pengendalian manajemen yang telah diterapkan pada CV. Maju Mapan : 


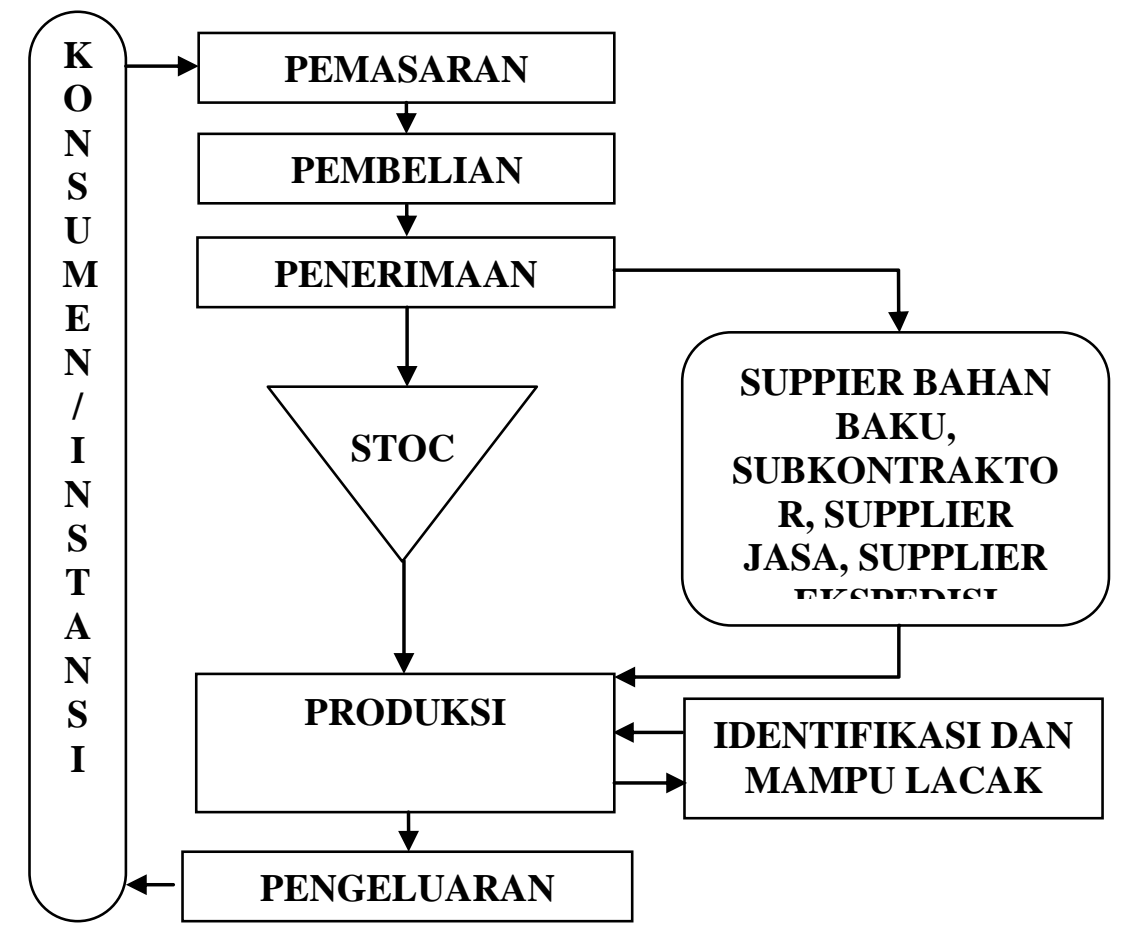

Sumber : Data Sekunder, 2017

\section{Prosedur Manajemen dalam Proses Produksi}

a. Bagian produksi

Bagian produksi berdasarkan SPP(Surat Perintah Produksi) dari Setper, menerbitkan perintah produksi (PP) yang berisikan spesifikasi produk, jumlah pesanan/pembuatan, target penyelesaian, jumlah dan jenis bahan yang dibutuhkan (RKB).

Bagian Produksi mendistribusikan Perintah Produksi (PP) kepada : Kepala Seksi Garmen, Kepala Seksi Logam, Kepala Seksi Tekstil, Gudang (hanya RKB)

Bagian seksi mendistribusikan kembali PP ke bagian kepala regu (Karu), yaitu: Karu Skir, Karu Tenun Terpal, Karu Tenun Webbing, Karu Celup, Karu Webbing, Karu Potong, Karu sablon, Karu jahit, Karu Assembling, Karu Packing, Karu Matras, Karu Salen, Karu Pelapisan Obat, Karu Pelapisan Cat, Karu Bengkel

Berdasarkan SSP dan Perintah Produksi, Bagian Produksi menyiapkan sarana dan fasilitas lainnya, dan meminta bahan baku ke Bagian Gudang dengan menggunakan Bukti Pengambilan Bahan. Kemudian melaksanakan proses produksi berdasarkan ketentan kerja yang telah ditetapkan.

b. Bagian Quality Control (QC)

Bagian QC melakukan pemeriksaan pada bahan masuk kedalam proses produksi, pemeriksaan barang produk setengah jadi dan pemeriksaan pada proses akhir / produk jadi.

Bagian QC mencatat, melaporkan hasil pemeriksaan, dan menerbitkan data pemeriksaan berdasarkan data pemeriksaan, serta memberikan label status pada hasil produk sebagai berikut :

1) Produk baik menggunakan label Biru.

2) Produk akhir masih dapat diperbaiki menggunakan label kuning.

3) Produk akhir rusak total menggunakan label merah. 


\section{c. Bagian Gudang}

Bagian Gudang menerima, mencatat, menyimpan, dan memelihara hasil produksi dan siap untuk melayani penyerahan produk ke pelanggan.

\section{Penyelesaian Masalah}

Dalam penyelesaian masalah dalam temuan audit ditentukan berdasarkan tahapan audit yang telah ditetapkan yaitu :

\section{a. Audit Pendahuluan}

Tahap pertama dalam prosedur audit adalah audit pendahuluan, pada tahap ini peneliti mencari informasi umum mengenai perusahaan, seperti profil perusahaan, latar belakang, kegiatan, program serta sistem yang akan diperiksa agar peneliti dapat memperoleh pemahaman yang menyeluruh mengenai perusahaan dan semua aspek penting dari perusahaan yang berkaitan dengan audit manajemen terutama terhadap fungsi pemakaian bahan baku.

b. Review

1) Perencanaan Produksi

Sebelum melaksanakan proses produksi maka diperlukan perencanaan anggaran yang ditentukan berdasarkan rencana produksi dan persediaan di awal maupun akhir periode. Namun dalam CV. Maju Mapan perencanaan produksi berdasarkan pada jumlah order dari setiap instansi pemesan, karena spesifikasi dari produk tersebut telah ditetapkan oleh instansi dan setiap periode/tahun berubah.

2) Pengawasan Produksi

Bagian QC melakukan pemeriksaan pada bahan masuk kedalam proses produksi, pemeriksaan barang produk setengah jadi dan pemeriksaan pada proses akhir / produk jadi.

Bagian QC mencatat, melaporkan hasil pemeriksaan, dan menerbitkan data pemeriksaan berdasarkan data pemeriksaan, serta memberikan label status pada hasil produk sebagai berikut :

(a) Produk baik menggunakan label Biru.

(b) Produk akhir masih dapat diperbaiki menggunakan label kuning.

(c) Produk akhir rusak total menggunakan label merah.

\section{c. Audit Terinci}

Berdasarkan hasil evaluasi terhadap fungsi pemakaian bahan baku pada perusahaan, akan dilakukan tahap berikutnya yaitu tahap audit terinci. Tujuan dari tahap audit ini untuk memperoleh informasi tentang pengolahan bahan baku, efektifitas pemakaian bahan baku serta membuat simpulan audit.

Berdasarkan temuan audit dalam tahap pendahuluan ditemukan beberapa permasalahan dalam proses produksi yakni :

1) Dalam proses tenun, satu orang operator mampu melakukan pengawasan terhadap dua mesin tenun otomatis, namun tenaga operator kadang tidak tersedia dan untuk tetap melakukan produksi, satu operator mengoperasikan empat mesin tenun sekaligus.

2) Persediaan kain dalam dalam proses pencelupan kadang kurang karena proses tenun sendiri untuk menghabiskan satu gulungan benang besar membutuhkan waktu dua hari.

3) Dalam proses penjahitan terdapat kesalahan jahit karena beberapa faktor seperti mesin dan sumber daya manusia atau SDM. Faktor mesin juga berpengaruh sepeti mesin jahit tidak berjalan dengan lancar atau bahkan rusak sehingga mengganggu produktifitas bahkan merusak produk. Sedangkan dalam hal SDM yaitu karyawan yang kurang 
berpengalaman atau karyawan baru dan kadang kurang produktif dibanding karyawan lainnya dan sering produk yang dihasilkan mengalami kerusakan.

Untuk memperoleh informasi tentang pengolahan bahan baku, efektifitas pemakaian bahan baku diperlukan data mengenai persediaan dan pemakaian bahan baku pada tahun 2014, 2015 dan 2016 seperti yang tercantum pada tabel berikut :

\begin{tabular}{|c|c|c|}
\hline Tahun & Kuantitas & Harga \\
\hline 2014 & 12755 & Rp $\quad 99,500$ \\
\hline 2015 & 12750 & $\mathrm{Rp} \quad 98,500$ \\
\hline 2016 & 9650 & Rp 120,000 \\
\hline
\end{tabular}

Sumber : Data Sekunder Diolah, 2017

Berdasarkan tabel 4.8 diatas tercantum jumlah pesanan dalam tiga tahun beserta harga yang ditetapkan. Seiring dengan kualitas produk yang semakin baik maka harga yang ditetapkan juga semakin naik. Seiring dengan harga yang semakin naik maka jumlah pesanan berkurang pada tahun 2015 dan 2016.

\begin{tabular}{|r|r|r|r|r|}
\hline Tahun & Pesanan & $\begin{array}{r}\text { Rencana } \\
\text { Produksi }\end{array}$ & $\begin{array}{r}\text { Produk } \\
\text { Rusak }\end{array}$ & Realisasi \\
\hline 2014 & 12755 & 12755 & 135 & 12620 \\
\hline 2015 & 12750 & 12750 & 117 & 12633 \\
\hline 2016 & 9650 & 9650 & 70 & 9580 \\
\hline
\end{tabular}

Sumber : Data Sekunder Diolah, 2017

Berdasarkan tabel 4.9 diatas dapat diketahui jika rencana pemakaian bahan baku tidak dapat mencapai realisasi karena terdapat beberapa kerusakan. Kerusakan tersebut berada dalam proses garmen atau jahit antara kain polyester dengan kain puring dan webbing sehingga mengganggu proses produksi yang efektif. Sementara untuk satu buah tas Ransel Punggung Kecil (RPK) membutuhkan bahan baku sebagai berikut :

\begin{tabular}{|c|l|c|c|}
\hline No. & \multicolumn{1}{|c|}{ BAHAN BAKU } & SATUAN & Per SET \\
\hline 1 & Kain polyester $100 \%$ & Meter & 0.35 \\
\hline 2 & Kain puring warna & Meter & 0.2 \\
\hline 3 & Klem tebal $\ell 2,5 \mathrm{~cm}$ & Meter & 1.16 \\
\hline 4 & Pita sineret $\ell 2,5 \mathrm{~cm}$ & Meter & 0.62 \\
\hline 5 & Lubang III lele kecil & Buah & 5 \\
\hline 6 & Lubang II kecil $2,5 \mathrm{~cm}$ & Buah & 4 \\
\hline 7 & Letter D kecil & Buah & 4 \\
\hline 8 & Ujung dop kecil & Buah & 5 \\
\hline 9 & Knop & Buah & 1 \\
\hline 10 & Ring & Buah & \\
\hline
\end{tabular}

Sumber : Data Sekunder, 2017

CV. Maju Mapan telah menetapkan bahwa rencana pemakaian bahan baku secara keseluruhan didasarkan pada kebutuhan per produk dan dikalikan dengan jumlah pesanan. Jadi jika terdapat kerusakan produk, maka produk tersebut akan diperbaiki atau dijahit ulang. CV. Maju Mapan tidak melakukan penyimpanan produk jadi tahun sebelumnya untuk 
pesanan tahun mendatang, karena spesifikasi dalam setiap periode berbeda sesuai dengan kebutuhan instansi, tren, model dan perkembangan teknologi.

\section{d. Pelaporan}

Tahap pelaporan bertujuan untuk membuat kesimpulan dari tahap-tahap audit yang telah dilakukan sebelumnya dan mengkomunikasikan hasil temuan audit termasuk rekomendasi dan diberikan kepada berbagai pihak yang berkepentingan.

\section{Analisis Sistem Pengendalian Manajemen}

Berdasarkan hasil analisis mengenai sistem pengendalian manajemen pada CV. Maju

Mapan khususnya terhadap fungsi pemakaian bahan baku adalah :

a. Bagian produksi

Bagian produksi berdasarkan SPP(Surat Perintah Produksi) dari Setper, menerbitkan perintah produksi (PP) yang berisikan spesifikasi produk, jumlah pesanan/pembuatan, target penyelesaian, jumlah dan jenis bahan yang dibutuhkan (RKB).

Bagian Produksi mendistribusikan Perintah Produksi (PP) kepada : Kepala Seksi Garmen, Kepala Seksi Logam, Kepala Seksi Tekstil, Gudang (hanya RKB)

Bagian seksi mendistribusikan kembali PP ke bagian kepala regu (Karu), yaitu: Karu Skir, Karu Tenun Terpal, Karu Tenun Webbing, Karu Celup, Karu Webbing, Karu Potong, Karu sablon, Karu jahit, Karu Assembling, Karu Packing, Karu Matras, Karu Salen, Karu Pelapisan Obat, Karu Pelapisan Cat, Karu Bengkel.

Berdasarkan SSP dan Perintah Produksi, Bagian Produksi menyiapkan sarana dan fasilitas lainnya, dan meminta bahan baku ke Bagian Gudang dengan menggunakan Bukti Pengambilan Bahan. Kemudian melaksanakan proses produksi berdasarkan ketentan kerja yang telah ditetapkan.

b. Bagian Quality Control (QC)

Bagian QC melakukan pemeriksaan pada bahan masuk kedalam proses produksi, pemeriksaan barang produk setengah jadi dan pemeriksaan pada proses akhir / produk jadi.

Bagian QC mencatat, melaporkan hasil pemeriksaan, dan menerbitkan data pemeriksaan berdasarkan data pemeriksaan, serta memberikan label status pada hasil produk sebagai berikut :

(1) Produk baik menggunakan label Biru.

(2) Produk akhir masih dapat diperbaiki menggunakan label kuning.

(3) Produk akhir rusak total menggunakan label merah.

c. Bagian Gudang

Bagian Gudang menerima, mencatat, menyimpan, dan memelihara hasil produksi dan siap untuk melayani penyerahan produk ke pelanggan.

Untuk mengantisipasi kerusakan produk, CV. Maju Mapan melakukan pengawasan terhadap proses produksi. Dan untuk mengatasi kerusakan produk, CV. Maju Mapan juga melakukan proses sortir, sehingga jika diketahui terdapat produk rusak maka akan ditahan dalam proses sortasi untuk kemudian dilakukan perbaikan.

\section{Analisis Fungsi Pemakaian Bahan Baku}

Fungsi pemakaian bahan baku dalam hal ini menyangkut proses produksi hingga produk jadi. Berdasarkan data yang diperoleh diketahui bahwa proses pemakaian bahan baku dalam tiga tahun terakhir adalah sebagai berikut: 


\begin{tabular}{|c|l|c|c|r|r|r|}
\hline NO & \multicolumn{1}{|c|}{ BAHAN BAKU } & SATUAN & Per SET & RENCANA & REALISASI & DEVIASI \\
\hline 1 & Kain polyester & Meter & 0.35 & 4,465 & 4,417 & 48 \\
\hline 2 & Kain puring & Meter & 0.2 & 2,550 & 2,524 & 26 \\
\hline 3 & Webbing dari polyester & \multicolumn{5}{|c|}{} \\
\cline { 2 - 7 } & Klem tebal $\ell 2,5 \mathrm{~cm}$ & Meter & 1.16 & 14,796 & 14,650 & 146 \\
\cline { 2 - 7 } & Pita sineret $\ell 2,5 \mathrm{~cm}$ & Meter & 0.62 & 7,908 & 7,825 & 78 \\
\hline
\end{tabular}

Sumber : Data Sekunder Diolah, 2017

Berdasarkan tabel diatas diketahui bahwa pemakaian bahan baku pada tahun 2014 mengalami deviasi berupa kerusakan produk dalam proses jahit sehingga mendapatkan label kuning dan perlu dilakukan perbaikan.

\begin{tabular}{|c|l|c|c|r|r|r|}
\hline NO & \multicolumn{1}{|c|}{ BAHAN BAKU } & SATUAN & Per SET & RENCANA & REALISASI & DEVIASI \\
\hline 1 & Kain polyester & Meter & 0.35 & 4463 & 4422 & 41 \\
\hline 2 & Kain puring & Meter & 0.2 & 2550 & 2527 & 23 \\
\hline 3 & $\begin{array}{l}\text { Webbing dari } \\
\text { polyester }\end{array}$ & \multicolumn{5}{|l}{} \\
\cline { 2 - 7 } & Klem tebal $\ell 2,5 \mathrm{~cm}$ & Meter & 1.65 & 21038 & 20883 & 155 \\
\cline { 2 - 8 } & Pita sineret $\ell 2,5 \mathrm{~cm}$ & Meter & 0.7 & 8925 & 8842 & 83 \\
\hline
\end{tabular}

Sumber : Data Sekunder Diolah, 2017

Berdasarkan tabel diatas diketahui bahwa pemakaian bahan baku pada tahun 2015 mengalami deviasi berupa kerusakan produk dalam proses jahit sehingga mendapatkan label kuning dan perlu dilakukan perbaikan. Deviasi berupa kerusakan pada tahun 2015 mulai menurun seiring dengan rencana produksi. Namun untuk deviasi webbing semakin meningkat karena spesifikasi tahun 2015 berbeda dengan tahun 2014.

\begin{tabular}{|c|l|c|c|r|r|r|}
\hline NO & \multicolumn{1}{|c|}{ BAHAN BAKU } & SATUAN & $\begin{array}{c}\text { Per } \\
\text { SET }\end{array}$ & RENCANA & REALISASI & DEVIASI \\
\hline 1 & Kain polyester & Meter & 0.35 & 3378 & 3353 & 25 \\
\hline 2 & Kain puring & Meter & 0.2 & 1930 & 1916 & 14 \\
\hline 3 & Webbing dari polyester & \multicolumn{5}{|l}{} \\
\cline { 2 - 7 } & Klem tebal $\ell 2,5 \mathrm{~cm}$ & Meter & 1.16 & 11194 & 11113 & 81 \\
\cline { 2 - 8 } & Pita sineret $\ell 2,5 \mathrm{~cm}$ & Meter & 0.62 & 5983 & 5940 & 43 \\
\hline
\end{tabular}

Sumber : Data Sekunder Diolah, 2017

Berdasarkan tabel diatas diketahui bahwa deviasi dari rencana dan realisasi pemakaian bahan baku pada tahun 2016 mulai menurun seiring dengan rencana produksi. Sementara mengenai spesifikasi produk sama dengan tahun 2014.

\begin{tabular}{|c|r|r|r|r|r|r|}
\hline \multirow{2}{*}{ TAHUN } & \multicolumn{3}{|c|}{ RENCANA } & \multicolumn{3}{c|}{ REALISASI } \\
\cline { 2 - 7 } & $\begin{array}{c}\text { Kain } \\
\text { Polyester }\end{array}$ & Kain Puring & Webbing & $\begin{array}{c}\text { Kain } \\
\text { Polyester }\end{array}$ & Kain Puring & Webbing \\
\hline $\mathbf{2 0 1 4}$ & 4465 & 2550 & 22704 & 4417 & 2524 & 22480 \\
\hline $\mathbf{2 0 1 5}$ & 4463 & 2550 & 29963 & 4422 & 2527 & 29725 \\
\hline $\mathbf{2 0 1 6}$ & 3378 & 1930 & 17177 & 3353 & 1916 & 17053 \\
\hline
\end{tabular}

Sumber : Data Sekunder Diolah, 2017

Pada tabel diatas diketahui bahwa pemakaian bahan baku pada tahun 2016 menurun dibandingkan dengan tahun sebelumnya. Hal tersebut disebabkan oleh jumlah pesanan yang 
datang pada tahun 2016 menurun. Namun mengenai efektifitas pemakaian bahan baku pada tahun 2016 cenderung dapat dikatakan efektif, khususnya kain Webbing yang berada di angka $0.72 \%$, dengan perhitungan efektifitas bahan baku sebagai berikut :

Selisih pemakaian bahan baku Webbing dari polyester :

1. Webbing dari polyester pada tahun 2014

$$
\begin{aligned}
& =\frac{\text { RKAP-Realisasi pemakaian pada akhir periode }}{\text { RKAP }} 100 \% \\
& =\quad \begin{array}{l}
(\text { RKAP }=\text { Rencana Kerja Anggaran Perusahaan }) \\
\frac{(22.704-22.480)}{22.704} \times 100 \%
\end{array} \\
& =\quad 0.99 \%
\end{aligned}
$$

2. Webbing dari polyester pada tahun 2015

$$
\begin{aligned}
& =\frac{\text { RKAP-Realisasi pemakaian pada akhir periode }}{\text { RKAP }} 100 \% \\
& (\text { RKAP }=\text { Rencana Kerja Anggaran Perusahaan }) \\
& =\frac{(29.963-29.725)}{29.963} \times 100 \% \\
& =\quad 0.79 \%
\end{aligned}
$$

3. Webbing dari polyester pada tahun 2016

$$
\begin{aligned}
= & \frac{\text { RKAP-Realisasi pemakaian pada akhir periode }}{\text { RKAP }} 100 \% \\
= & \left(\frac{17.177-17.053}{17.177}\right) \times 100 \% \\
= & 0.72 \%
\end{aligned}
$$

Dengan hasil perhitungan secara keseluruhan dapat dilihat dalam tabel berikut

\begin{tabular}{|c|r|r|r|r|}
\hline TAHUN & \multicolumn{1}{|c|}{ RENCANA } & \multicolumn{1}{|c|}{ REALISASI } & \multicolumn{1}{|c|}{ SELISIH } & PERSEN \\
\hline $\mathbf{2 0 1 4}$ & 4465 & 4417 & 48 & $1.08 \%$ \\
\hline $\mathbf{2 0 1 5}$ & 4463 & 4422 & 41 & $0.92 \%$ \\
\hline $\mathbf{2 0 1 6}$ & 3378 & 3353 & 25 & $0.74 \%$ \\
\hline
\end{tabular}

Sumber : Data Sekunder Diolah, 2017

Tabel Perbandingan Rencana dan Realisasi kain puring

\begin{tabular}{|r|r|r|r|r|}
\hline TAHUN & \multicolumn{1}{|c|}{ RENCANA } & \multicolumn{1}{c|}{ REALISASI } & \multicolumn{1}{|l|}{ SELISIH } & PERSEN \\
\hline $\mathbf{2 0 1 4}$ & 2550 & 2524 & 26 & $1.02 \%$ \\
\hline $\mathbf{2 0 1 5}$ & 2550 & 2527 & 23 & $0.90 \%$ \\
\hline $\mathbf{2 0 1 6}$ & 1930 & 1916 & 14 & $0.73 \%$ \\
\hline
\end{tabular}

Sumber : Data Sekunder Diolah, 2017 
Tabel Perbandingan Rencana dan Realisasi kain Webbing

\begin{tabular}{|r|r|r|r|r|}
\hline TAHUN & \multicolumn{1}{|c|}{ RENCANA } & \multicolumn{1}{|c|}{ REALISASI } & \multicolumn{1}{l|}{ SELISIH } & \multicolumn{1}{l|}{ PERSEN } \\
\hline $\mathbf{2 0 1 4}$ & 22704 & 22480 & 224 & $0.99 \%$ \\
\hline $\mathbf{2 0 1 5}$ & 29963 & 29725 & 238 & $0.79 \%$ \\
\hline $\mathbf{2 0 1 6}$ & 17177 & 17053 & 124 & $0.72 \%$ \\
\hline
\end{tabular}

Sumber : Data Sekunder Diolah, 2017

Berdasarkan tabel diatas diketahui bahwa persentase perbandingan antara rencana dan realisasi pemakaian bahan baku kain webbing pada tahun 2014 hingga 2016 semakin mendekati efektif, hal ini disebabkan oleh beberapa kerusakan produk yang terjadi dalam proses jahit semakin berkurang. Disamping itu kain webbing tidak menimbulkan bahan baku sisa, seperti terdapat pada kain polyester dan kain puring yang harus melewati proses pemotongan kain atau penyetelan kain sehingga terdapat sisa kain yang terbuang. Namun perusahaan tetap perlu melakukan upaya demi menekan selisih pemakaian bahan baku sehingga dapat mendekati $0 \%$ agar dapat dikatakan efektif.

\section{Pelaporan}

Setelah melewati beberapa proses audit manajenen dalam Fungsi Pemakaian Bahan Baku maka penulis perlu melakukan pelaporan mengenai hasil temuan audit yang diperoleh, hasil temuan tersebut meliputi :

a. Dalam proses scouring, ketersediaan kain dalam dalam proses scouring kadang kurang karena proses tenun sendiri membutuhkan waktu dua hari untuk menghabiskan satu gulungan benang besar.

b. Rencana pemakaian bahan baku terhambat karena terdapat beberapa kerusakan proses garmen antara kain polyester dengan kain puring dan webbing. Kerusakan disebabkan oleh faktor kinerja mesin yaitu mesin yang kadang macet, disamping itu keterampilan karyawan juga berpengaruh seperti karyawan baru yang belum terbiasa dalam penjahitan produk sehingga terjadi salah jahit dan jahit kurang lurus.

c. Perusahaan mengadakan program pelatihan kerja setiap tahun, namun dalam pelaksanaannya program tersebut kadang tidak dilaksanakan. Sehingga kerusakan dalam proses garmen dominan disebabkan oleh faktor keterampilan karyawan terutama terhadap karyawan baru yang mengalami salah penjahitan.

Jika terdapat kerusakan produk yang parah dengan label merah, maka produksi harus diulang dari awal. Walaupun pada pelaksanaannya kesalahan tersebut sangat jarang terjadi. Sementara Instansi pemesan telah menetapkan jumlah produk dan waktu pengiriman pesanan, dan jika terdapat kekurangan produk ataupun melebihi waktu yang ditentukan maka perusahaan akan menerima sanksi berupa denda.

Setelah diketahui beberapa temuan audit dalam Fungsi Pemakaian Bahan Baku maka penulis perlu melakukan rekomendasi perbaikan terhadap perusahaan terkait dengan temuan audit tersebut.

Mengenai proses tenun yang memerlukan waktu yang relatif lebih lama maka perlu mengadakan persediaan kain polyester terlebih dahulu, sehingga jika terdapat pesanan produksi, bagian pencelupan tidak perlu menunggu bagian tenun.

Terkait temuan berupa kerusakan dalam proses garmen kain polyester dengan kain puring dan webbing. Kerusakan disebabkan oleh faktor mesin yaitu mesin kadang macet, sehingga menghambat produktifitas, maka untuk mengatasi permasalahan tersebut perusahaaan 
perlu melakukan pemeriksaan mesin sebelum melakukan produksi khususnya untuk proses penjahitan produk.

Mengenai faktor sumber daya manusia, kerusakan disebabkan oleh kurangnya keterampilan karyawan khususnya karyawan baru yang belum terbiasa dalam melakukan penjahitan produk, sehingga terjadi kesalahan jahit. Maka untuk mengatasi masalah tersebut perusahaan perlu mengadakan pelatihan kerja terhadap karyawan. Perusahaan sebenarnya telah malaksanakan program pelatihan kerja per tahun, namun program tersebut kadang tidak dilaksanakan. Program pelatihan kerja merupakan hal yang penting bagi perusahaan karena dapat menambah kemampuan, keterampilan dan keahlian sumber daya manusia yang nantinya juga berpengaruh terhadap produktifitas perusahaan.

Perusahaan telah menetapkan target hasil produksi berdasarkan jumlah pesanan, sehingga jika terdapat kerusakan bahan baku dan perlu mendapatkan label merah, maka produksi akan diulang dari awal. Namun dalam pelaksanaannya kerusakan dengan label merah sangat jarang terjadi walau demikian perusahaan perusahaan perlu untuk mengadakan langkah antisipasi agar produksi tidak melampaui waktu yang telah ditentukan. Perusahaan dapat melakukan produksi lebih dengan menambah efektifitas maksimal dengan selisih efektifitas pemakaian bahan baku. Dan jika terdapat produk berlebih maka perusahaan dapat menambah daerah pemasaran disekitar perusahaan atau masyarakat luas.

\section{SIMPULAN}

Berdasarkan hasil penelitian maka dapat diambil kesimpulan sebagai berikut :

1. CV. Maju Mapan telah memberikan wewenang kepada bagian Quality Control untuk melakukan pemeriksaan khususnya terhadap pemakaian bahan baku dari bahan baku mentah, produk setengah jadi hingga produk jadi. Hasil produksi dibedakan berdasarkan kualitas yakni label biru untuk produk kualitas baik, label kuning produk yang perlu perbaikan, label merah untuk produk rusak total.

2. Dalam proses produksi terdapat beberapa hambatan seperti dalam proses tenun yang membutuhkan waktu relative lebih lama karena untuk menghabiskan satu gulungan benang besar membutuhkan waktu dua hari. Sehingga dalam proses scouring terganggu karena harus menunggu hasil tenun selesai.

3. Dalam proses jahit terdapat beberapa hambatan berupa salah jahit, hal ini disebabkan oleh faktor kinerja mesin yaitu mesin yang kadang macet, dan keterampilan karyawan khususnya karyawan baru yang belum terbiasa dalam penjahitan produk.

4. Dalam periode 2014 hingga 2016 bagian produksi tidak pernah mendapatkan label merah untuk hasil produk tas Ransel Punggung Kecil. Untuk produk dengan label kuning efektifitas proses produksi kurang maksimal, namun selisih perencanaan dengan realisasi semakin baik yakni mulai mendekati 0\%. Pada tahun 2016 selisih efektifitas pemakaian bahan baku kain polyester $0.74 \%$, kain puring $0.73 \%$, webbing polyester $0.72 \%$.

5. Perusahaan telah menetapkan target hasil produksi berdasarkan jumlah pesanan, sehingga jika terdapat kerusakan bahan baku dan perlu mendapatkan label merah, maka produksi akan diulang dari awal untuk memenuhi jumlah pesanan.

\section{SARAN}

Berdasarkan kesimpulan diatas dapat diberikan saran-saran untuk perusahaan sebagai berikut:

1. Perusahaan perlu untuk mengadakan persediaan hasil tenun, sehingga dalam proses scouring tidak perlu menunggu lama untuk melakukan produksi. 
2. Perusahaan perlu untuk melakukan pemeriksaan mesin secara merata sebelum melakukan produksi karena terdapat hambatan berupa mesin yang kadang macet.

3. Mengenai faktor Sumber daya manusia terkait keterampilan karyawan khususnya karyawan baru yang belum terbiasa dalam melakukan penjahitan produk, perusahaan perlu mengadakan pelatihan kerja terhadap karyawan agar dapat menambah kemampuan, keterampilan dan keahlian karyawan.

4. Perusahaan perlu untuk melakukan langkah antisipasi jika nantinya terdapat produk dengan label merah. Perusahaan dapat melakukan perencanaan produksi lebih dari pesanan instansi dengan menambah efektifitas maksimal dengan selisih efektifitas pemakaian bahan baku. Dan jika hasil produksi lebih dari order maka perusahaan dapat menambah daerah pemasaran disekitar perusahaan atau masyarakat luas.

\section{DAFTAR PUSTAKA}

Akmal., Drs Ak., PIA., MM 2009, Pemeriksaan Manajemen Internal Audit, Edisi Kedua, Penerbit Indeks, Jakarta

Bhayangkara, IBK.,S.E., MM., 2008, Audit Manajemen Prosedur dan Implementasi, Penerbit Salemba Empat, Jakarta.

Imam Soeharto., Ir, 1999, Manajemen Proyek, Edisi Kedua, Penerbit Erlangga, Jakarta.

Supriyono, R.A., Sistem Pengendalian Manajemen, Edisi Pertama, Penerbit BPFE YOGYAKARTA, Yogyakarta.

Tunggal, Amin W., Drs., Ak., MBA, 2003, Audit Manajemen Kontemporer, Edisi Refisi, Penerbit Harvarindo, Jakarta.

Tunggal, Amin W.,Drs Ak., MBA, 1992, Manajemen Audit Suatu Pengantar, Cetakan Pertama, Penerbit PT. Rineka Cipta, Jakarta.

Schmelz, E.M., and Merill, A.H., 1998. Ceramides and Ceramide Metabolites in Cell Regulation: Evident for Dietarysphingolipids As inhibitors of Colon Carcinogenesis. Nutrition, 14:717719.

Schlegel, Hg. 1994. Mikrobiologi Umum. Edisi Keenam. Gadjah Mada University Press, Yogyakarta.

Schoevers, A. and Britz, T.J. 2003. Influence of Different Culturing Conditions on Kefir Grain Increase. In. J. Dairy Tech., 56(3): 183-187.

Shavit, E., 2008. Renewed Interest in Kefir, the Ancient Elixir of Longevity. Volume 1:2 Summer Bul., 1(2): 14-18.

Sharma, S., 1996. Applied Multivariate Techniques. John Wiley and Sons, Inc., New York.

Shihata, A. and Shah, N.P., 2000. Proteolytic Profiles of Yogurt and Probiotic Bacteria. Int. Dairy J., 10: 401-408.

Song, C. Y., Chen, W. L., Yang, M. C., Huang, J. P. and Mao. S. J. T. 2005. Epitope mapping of a monoclonal antibody specific to bovinedry milk: Involvement of residues 66-76 of strand D in thermal denatured $\beta$-lactoglobulin. J. Biol. Chem. 280:3574-358

Tedjakusuma, R. dan Muryani, S.H., 2001. Analisis Faktor Yang Mempengaruhi Perilaku Konsumen Dalam Pembelian Air Minum Mineral Di Kota Surabaya. J. Pen. Dinamika Sosial, 2: 50-58. 
Ulusoy, B.H., Çolak. H, Hampikyan.H, and Erkan, M.E., 2007. An in Vitro Study on The Antibacterial Effect of Kefir Against Some FoodBorne Pathogens. Turk Mikrobiyol Cem Derg., 37 (2): 103-107.

Umar, H., 2005. Riset Pemasaran Dan Perilaku Konsumen. Gramedia Pustaka Utama. Jakarta Research Center. Jakarta.

Usmiati, S. dan Sudono, A. 2004. Pengaruh Starter Kombinasi Bakteri Dan Khamir. Terhadap Sifat Fisiko-kimia dan Sensori Kefir. J. Pascapanen, I(1): 12-21.

Valkonen, K. H.,. Marttinen, N., Malinen, H.L., Jaakola, V.P. and. Alatossava, T., 2011. Purification and Characterization of $\beta$-Lactoglobulin Genetic Variant A and B By Using Preparative Elution Electrophoresis and Isoelectric Focusing. Preparative Electrophoresis. Bulletin Bio Rad,. Tech. Note no. 2262, Hercules.

Van den Berg, J.T.C., 1987. Higiene Susu dan Teknologi Produk Susu. Diterjemahkan oleh Purnomo, H., Padaga, M.C. dan Sawitri, M.E. Program Studi Teknologi Hasil Ternak. Fakultas Peternakan. Universitas Brawijaya, Malang.

Walter, E.H.M. 2007. Testing The Sensory Acceptability of Biltong formulated With Different Spces. J. Agric. Res., 2: 574-577.

Wang, Y., Zheng, Y, Jiang, M., Liang, C. and Liu, Z.L., 2011. Comparison of The Biochemical Components and Characteristic of Milk Between Tibetan Sheep Goat in Neighboring Area. Afr. J. Biotech.10(11): 2092-2100.

Xiao, J.Z., Kondo, S., Takahashi, N., Miyaji, K., Oshika, K., Hiramatsu, A. Iwatsuki, K., Kokubo, S. and Hosono, A., 2003. Effect of Milk Products Fermented by Bifidobacterium Longum on Blood Lipids in Rats and Healthy Adult Male Volunteers. J. Dairy Sci., 86:2452-2461.

Xu, Z. M., Emmanouelidou, D. G., Raphaelides, S. N. and Antoniou, K. D., 2008. Effects of Heating Temperature and Fat Content on The Structure Development of Set Yogurt. J. Food Eng., 85(4):590-597.

Yoshida, Sh., 1990. Isolation of lactoglobulin an lactalbumun by Gel Filtration Using Sephacryl S-200 and Purification by Diethylaminoethyl Ion-Exchange Chromatography. J. Dai. Sci., 73:2292-2298. 